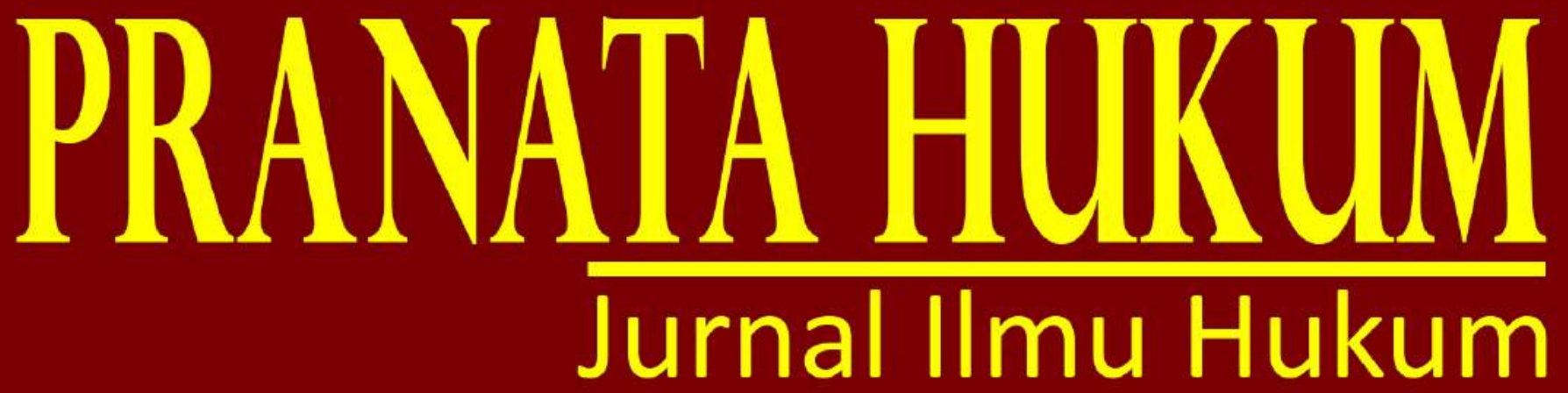

e-ISSN 2685-3213 | p-ISSN 1907-560X

SINERGITAS PEMERINTAHAN DESA DALAM PEMBENTUKAN PERATURAN DESA Anggalana

PENYELESAIAN SENGKETA PERBANKAN BERKAITAN DENGAN PERLINDUNGAN KONSUMEN Dian Herlambang, Muhammad Ridho Wijaya

ANALISIS KOMPARASI ANTARA PERLINDUNGAN PATEN BIASA DENGAN PATEN SEDERHANA BERDASARKAN UNDANG-UNDANG PATEN

Erlina, Melisa Safitri

KONSEPSI NEGARA HUKUM PANCASILA DAN IMPLEMENTASINYA DI INDONESIA Tubagus Muhammad Nasarudin

ANALISIS KEBIJAKAN PEMUNGUTAN RETRIBUSI PELAYANAN PERSAMPAHAN KEBERSIHAN DALAM RANGKA PENINGKATAN PENDAPATAN ASLI DAERAH DI KOTA BANDAR LAMPUNG Pertiwi Agustina RA, Lintje Anna Marpaung, Herlina Ratna Sumbawa Ningrum

ANALISIS KEDUDUKAN PERATURAN DESA PASCA PENGESAHAN UNDANG-UNDANG NOMOR 6 TAHUN 2014 TENTANG DESA DI DESA BADRAN SARI DAN NAMBAH REJO KABUPATEN LAMPUNG TENGAH

Baharudin, Indah Satria, Ramanda Ansori

FANATISME DAN EKSISTENSI NILAI-NILAI DEMOKRASI KADER NAHDLATUL ULAMA KOTA METRO PADA PILPRES 2019

Hendra Irawan, Ika Selviana

PERLINDUNGAN HUKUM TERHADAP PEMENANG LELANG BARANG RAMPASAN NEGARA BERUPA KENDARAAN RODA DUA YANG DIEKSEKUSI DENGAN CARA LELANG OLEH KEJAKSAAN

Okta Vianus Puspa Negara, Zainab Ompu Jainah, S. Tri Herlianto

ANALISIS PERTANGGUNGJAWABAN PELAKU TINDAK PIDANA MENGGANDAKAN SURAT PALSU UNTUK BEKERJA DI PT. GREAT GIANT PINEAPPLE HUMAS JAYA

Helmi Rangkuti, Ketut Seregig, Tami Rusli

MAGISTER HUKUM

UNIVERSITAS BANDAR LAMPUNG

\begin{tabular}{c|c|c|c|l}
$\begin{array}{c}\text { PRANATA } \\
\text { HUKUM }\end{array}$ & $\begin{array}{c}\text { Volume } \\
15\end{array}$ & $\begin{array}{c}\text { Nomor } \\
1\end{array}$ & $\begin{array}{c}\text { Halaman } \\
1-119\end{array}$ & $\begin{array}{l}\text { Bandar } \\
\text { Lampung } \\
\text { Januari } 2020\end{array}$ \\
\hline
\end{tabular}




\section{PRANATA HUKUM}

Jurnal Ilmu Hukum

Magister Hukum

Universitas Bandar Lampung

Terbit Pertama Kali, Juli 2006

Terbit Dua Kali Setahun, Setiap Januari dan Juli

EDITOR IN-CHIEF

Prof. Dr. Lintje Anna Marpaung, S.H., M.H

EDITORIAL BOARDS MEMBERS

Dr. Bambang Hartono, S.H., M.Hum

Dr. Tami Rusli, S.H., M.Hum

Dr. Erlina B, S.H., M.H

Dr. Zainab Ompu Jainah, S.H., M.H

Dr. Zulfi Diane Zaini, S.H., M.H

MANAGING EDITOR

Indah Satria, S.H., M.H

ASSISTANT EDITORS

Yulia Hesti, S.H., MH

Shany Carolina Mawuntu

\section{PENYUNTING AHLI (MITRA BESTARI)}

Prof. Dr. I Gusti Ayu Ketut Rachmi Handayani, S.H., M.M (Universitas Sebelas Maret)

Prof. Dr. I Gede A.B Wiranata, S.H., M.H (Universitas Lampung)

Dr. Nurhadiantomo, S.H., M.Hum (Universitas Muhammdiyah Surakarta)

Dr. Erina Pane, S.H., M.H (UIN Lampung)

\section{Alamat: \\ Kampus B Universitas Bandar Lampung}

Jl. Z.A Pagar Alam No.89 Labuhan Ratu, Bandar Lampung 35142

Telp: 0721-789825 Fax: 0721-770261

Email: jurnal.mh@ubl.ac.id

Jurnal PRANATA HUKUM dimaksudkan sebagai media komunikasi ,edukasi dan informasi ilmiah bidang ilmu hukum. Sajian dan kemasan diupayakan komunikatif melalui bahasa ilmiah.

Redaksi mengundang semua elemen masyarakat ,baik civitas akademika, praktisi , lembaga masyarakat, maupun perorangan yang berminat terhadap bidang hukum untuk berpartisipasi mengembangkan gagasan, wawasan, dan pengetahuan melalui tulisan untuk dimuat dalam jurnal ini. Melalui PRANATA HUKUM diharapkan terjadi proses pengembangan bidang hukum sebagai bagian penting dari rangkaian panjang proses memajukan masyarakat bangsa 


\title{
ANALISIS KEBIJAKAN PEMUNGUTAN RETRIBUSI PELAYANAN PERSAMPAHAN KEBERSIHAN DALAM RANGKA PENINGKATAN PENDAPATAN ASLI DAERAH DI KOTA BANDAR LAMPUNG
}

\author{
Pertiwi Agustina RA, ${ }^{1}$ Lintje Anna Marpaung, ${ }^{2}$ \\ Herlina Ratna Sumbawa Ningrum. ${ }^{3}$
}

\begin{abstract}
The policy of the collection of hygiene waste service in order to increase the regional genuine income has been implemented but not maximally. The implementation is done by planning, implementing a means or a work device that facilitates the implementation of the collection of waste services effectively and efficiently and implement the mechanism of retribution and implement a clear evaluation system. The inhibitory factors of the implementation of the collection of waste services/hygiene is still low understanding of the subject of retribution of local legal products concerning the levy of waste services/hygiene and still low awareness of the subject of retribution to the levy which is considered to be incriminated due to feel the obligation of paying tax to Bandar Lampung city government.
\end{abstract}

\section{Keywords: policies, retribution, waste services}

\section{PENDAHULUAN}

Menurut Pasal 1 angka (1) Undang-Undang Nomor 18 Tahun 2008 tentang Pengelolaan Sampah, disebutkan sampah adalah sisa kegiatan sehari hari manusia atau proses alam yang berbentuk padat atau semi padat berupa zat organik atau anorganik bersifat dapat terurai atau tidak dapat terurai yang dianggap sudah tidak berguna lagi dan dibuang ke lingkungan. Sampah adalah suatu yang tidak dikehendaki lagi oleh yang punya dan bersifat padat. Sampah merupakan konsekuensi dari adanya aktifitas manusia. Setiap aktifitas manusia pasti menghasilkan buangan atau sampah. Jumlah atau volume sampah sebanding dengan tingkat konsumsi kita terhadap barang/material yang kita gunakan sehari-hari. Demikian juga dengan jenis sampah, sangat tergantung dari jenis material yang kita konsumsi. Oleh karena itu pegelolaan sampah tidak bisa lepas juga dari 'pengelolaan' gaya

\footnotetext{
1 Mahasiswa Pascasarjana Magister Hukum Universitas Bandar Lampung, pertiwiagustina@gmail.com

2 Dosen Pascasarjana Magister Hukum Universitas Bandar Lampung, lintje@ubl.ac.id

3 Dosen Pascasarjana Magister Hukum Universitas Bandar Lampung, herlina@ubl.ac.id
} 
idup masyarakat. ${ }^{4}$

Arti penting pengelolaan sampah bagi Pemerintah Daerah adalah adanya tuntutan pada era otonomi daerah untuk dapat melaksanakan pelayanan kepada masyarakat, termasuk di dalamnya pelayanan persampahan secara baik dalam rangka mewujudkan kelestarian lingkungan hidup. Pada pada sisi lain masyarakat yang menerima layanan dikenakan kewajiban membayar retribusi atas pelayanan persampahan yang diberikan. Pemerintah Kota Bandar Lampung telah memberlakukan Peraturan Daerah Nomor 5 Tahun 2011 tentang Retribusi Jasa Umum Pelayanan Persampahan.

Pemungutan retribusi pelayanan persampahan kebersihan dilaksanakan oleh Dinas Lingkungan Hidup Kota Bandar Lampung, dasar hukumnya adalah Peraturan Daerah Kota Bandar Lampung Nomor 7 Tahun 2016 tentang Pembentukan dan Susunan Perangkat Daerah Kota Bandar Lampung. Selain itu dasar hukum lainnya adalah pemberlakuan Peraturan Walikota Bandar Lampung Nomor 47 Tahun 2016 tentang Tugas, Fungsi dan Tata Kerja Dinas Lingkungan Hidup Kota Bandar Lampung.

Salah satu bidang pada organisasi Dinas Lingkungan Hidup yang secara khusus mengelola persampahan adalah Bidang Pengelolaan Sampah. Pasal 5 ayat (1) huruf d Peraturan Walikota Bandar Lampung Nomor 47 Tahun 2016 menjelaskan bahwa Bidang Pengelolaan Sampah terdiri atas tiga seksi yaitu Seksi Pengelolaan Sampah, Seksi Sarana Prasarana Sampah dan Seksi Pengembangan Teknologi dan Inovasi Persampahan. Tugas pokok Bidang Pengelolaan Sampah adalah merumuskan dan melaksanakan kebijakan serta kewenangan di bidang pengelolaan sampah, termasuk dalam pemungutan retribusi pelayanan persampahan kebersihan.

Retribusi daerah merupakan salah satu sumber Pendapatan Asli Daerah (PAD) sebagai pungutan atau pembayaran atas jasa atau pemberian izin tertentu yang khusus disediakan dan/atau diberikan oleh Pemerintah Daerah untuk kepentingan orang pribadi atau badan. Retribusi daerah sebagai pembayaran atas penggunaan barang atau jasa yang disediakan untuk umum oleh pemerintah, maka penarikannya dilakukan umumnya di tempat pemakaian. Retribusi dapat juga ditagihkan kepada badan atau orang pribadi atas dasar pembayaran dengan penggunaan terbatas (dijatahkan) atau pembayaran dengan periode tertentu yang telah disepakati. Problem yang dihadapi dalam pemungutan retribusi pelayanan persampahan kebersihan saat ini adalah masih adanya oknum pegawai yang melakukan pemungutan retribusi tidak sesuai dengan prosedur yang berlaku, sehingga berpotensi mengurangi penerimaan Pendapatan Asli Daerah, karena uang retribusi yang didapatkan tersebut tidak disetorkan kepada bendahara dan tidak masuk ke dalam kas daerah. Hal ini menjadi suatu persoalan yang harus diselesaikan

${ }^{4}$ Dimas Harjoko. 2012. Sampah dalam Kebijakan Pemerintah, UNS, Semarang, hlm .23. 
oleh Dinas Lingkungan Hidup Kota Bandar Lampung agar pemungutan retribusi pelayanan persampahan kebersihan dapat dilaksanakan secara maksimal. Berdasarkan latar belakang di atas, maka permasalahan dalam penelitian ini dirumuskan yaitu bagaimanakah kebijakan pemungutan retribusi pelayanan persampahan kebersihan dalam rangka peningkatan pendapatan asli daerah di Kota Bandar Lampung? apakah faktor-faktor penghambat kebijakan pemungutan retribusi pelayanan persampahan kebersihan dalam rangka peningkatan pendapatan asli daerah di Kota Bandar Lampung?

Metode penelitian yang digunakan adalah yuridis normatif dan empiris. Prosedur pengumpulan data dilakukan dengan studi pustaka dan studi lapangan. Data yang diperoleh selanjutnya dianalisis secara yuridis kualitatif. Hasil penelitian ini dideskripsikan dalam bentuk penjelasan dan uraian kalimat yang mudah dibaca dan dimengerti untuk diinterprestasikan dan ditarik kesimpulan secara umum yang didasarkan fakta-fakta yang bersifat khusus terhadap pokok bahasan yang diteliti

\section{PEMBAHASAN}

\section{A. Kebijakan Pemungutan Retribusi Pelayanan Persampahan Kebersihan Dalam Rangka Peningkatan Pendapatan Asli daerah di Kota Bandar Lampung}

Pemungutan retribusi pelayanan persampahan kebersihan dalam rangka peningkatan Pendapatan Asli Daerah di Kota Bandar Lampung dilaksanakan berdasarkan Peraturan Daerah Kota Bandar Lampung Nomor 5 Tahun 2011 tentang Retribusi Jasa Umum. Pasal 2 huruf b Perda ini menyatakan bahwa jenis retribusi jasa umum dalam peraturan daerah ini salah satunya adalah retribusi Pelayanan Persampahan/Kebersihan. Menurut Pasal 9 Peraturan Daerah Kota Bandar Lampung Nomor 5 Tahun 2011 tentang Retribusi Jasa Umum diketahui bahwa retribusi pelayanan persampahan/ kebersihan dipungut retribusi sebagai pembayaran atas penyediaan jasa pelayanan persampahan/kebersihan yang diselenggarakan oleh Pemerintah Daerah. Pasal 10 Peraturan Daerah Kota Bandar Lampung Nomor 5 Tahun 2011 tentang Retribusi Jasa Umum:

(1) Objek Retribusi Pelayanan Persampahan/Kebersihan adalah pelayanan Persampahan/Kebersihan yang diselenggarakan oleh Pemerintah Daerah meliputi:
a. pengambilan/pengumpulan sampah dari sumbernya ke lokasi pembuangan sementara;
b. pengangkutan sampah dari sumbernya dan/atau lokasi pembuangan sementara ke lokasi pembuangan/pembuangan akhir


sampah;

c. penyediaan lokasi pembuangan/pemusnahan akhir sampah.

(2) Dikecualikan dari Objek Retribusi Pelayanan adalah persampahan/Kebersihan Pelayanan Kebersihan Jalan Umum, Taman, Tempat Ibadah, Sosial, dan Tempat Umum lainnya.

Subjek retribusi pelayanan persampahan/kebersihan menurut Pasal 11 Peraturan Daerah Kota Bandar Lampung Nomor 5 Tahun 2011 tentang Retribusi Jasa Umum adalah orang pribadi atau badan yang menggunakan atau menikmati pelayanan persampahan/kebersihan yang diselenggarakan oleh pemerintah daerah. Berdasarkan hasil wawancara dengan Sahriwansah selaku Kepala Dinas Lingkungan Hidup Kota Bandar Lampung, diketahui bahwa pelaksana kebijakan pemungutan retribusi pelayanan persampahan kebersihan dalam rangka peningkatan Pendapatan Asli Daerah Berdasarkan Perda Nomor 5 Tahun 2011 tentang Retribusi Jasa Umum adalah Dinas Lingkungan Hidup Kota Bandar Lampung. Secara operasional pelaksanaan kebijakan ini didasarkan pada Peraturan Wali Kota Bandar Lampung Nomor 8 Tahun 2019 tentang Tata Cara Pelaksanaan Pemungutan Retribusi Pelayanan Persampahan/Kebersihan pada Dinas Lingkungan Hidup.

Cara mengukur tingkat penggunaan jasa diatur dalam Pasal 3 Peraturan Wali Kota Bandar Lampung Nomor 8 Tahun 2019:

(1) Tingkat Penggunaan Pelayanan Persampahan/Kebersihan diukur berdasarkan Jenis dan Volume sampah.

(2) Jenis sampah sebagaimana dimaksud pada ayat (1) adalah sampah organic dan non organic.

(3) Dalam hal volume sampah sulit diukur, maka volume sampah dimaksud dapat ditaksir dengan berbagai pendekatan antara lainnya berdasarkan jenis bangunan rumah tangga, perdagangan, industri, dan jasa.

Berdasarkan hasil wawancara kepada Hayati selaku Staf Retribusi pada Dinas Lingkungan Hidup Kota Bandar Lampung diketahui bahwa wilayah Pemungutan Retribusi adalah di tempat kegiatan Pelayanan Persampahan/Kebersihan yang dilaksanakan dalam Wilayah Kota Bandar Lampung. Pemberlakuan Peraturan Wali Kota Bandar Lampung Nomor 8 Tahun 2019 tentang Tata Cara Pelaksanaan Pemungutan Retribusi Pelayanan Persampahan/Kebersihan pada Dinas Lingkungan Hidup menunjukkan adanya penerapan prinsip kepastian hukum dalam penerimaan retribusi pelayanan persampahan/kebersihan.

Pasal 6 Peraturan Wali Kota Bandar Lampung Nomor 8 Tahun 2019 menjelaskan bahwa untuk mendapatkan data Wajib Retribusi di Laksanakan Pendaftaran dan/atau Pendataan terhadap Wajib Retribusi. Kegiatan 
Pendaftaran dan/atau Pendataan Wajib Retribusi diawali dengan mempersiapkan SPT Tim Pendataan dan Formulir Pendaftaran /Pendataan. Hasil dari Pendaftaran dan/atau Pendataan sebagai bahan mengisi data atau membuat daftar Induk Wajib Retribusi. Daftar Induk Wajib Retribusi dapat dipergunakan sebagai Penetapan NPWRD atau sejenisnya.

Menurut penjelasan Yudi Susandi selaku petugas pemungut retribusi, diketahui bahwa sesuai dengan ketentuan Pasal 8 Peraturan Wali Kota Bandar Lampung Nomor 8 Tahun 2019 menjelaskan bahwa tata cara pembayaran retribusi dilakukan di Kas Daerah atau tempat lainnya yang ditunjuk sesuai dengan waktu yang ditentukan dengan menggunakan SKRD atau dokumen lain yang dipersamakan berupa karcis.Dalam hal Pembayaran dilakukan ditempat lain yang ditunjuk maka hasil Penerimaan Retribusi Daerah harus disetor ke Kas Daerah selambat-lambatnya 1 x 24 jam atau dalam waktu yang ditentukan oleh Walikota. Apabila Pembayaran Retribusi dilakukan setelah lewat waktu yang telah ditentukan sebagaimana dimaksud pada ayat (1), maka akan dikenakan sanksi Administrasi berupa bunga sebesar 2\% (dua persen) dari nilai Retribusi, dengan menerbitkan Surat Tagihan Retribusi Daerah (STRD). Pembayaran Retribusi dilakukan secara tunai yang dipungut oleh petugas penagih retribusi yang dilengkapi Surat Perintah Tugas (SPT) resmi. Hasil Pungutan Retribusi merupakan Pendapatan Daerah dan sepenuhnya disetor ke Kas Daerah.

Pasal 9 Peraturan Wali Kota Bandar Lampung Nomor 8 Tahun 2019 menjelaskan bahwa wajib Retribusi dapat mengajukan keberatan hanya Kepada Walikota melalui Kepala Dinas atas Surat Ketetapan Retribusi Daerah (SKRD) yang diterbitkan. Permohonan Keberatan diajukan secara tertulis dalam bahasa Indonesia disertai alasan-alasan yang jelas. Selanjutnya Kepala Dinas melakukan penelitian dan mempelajari data permohonan keberatan yang disampaikan. Permohonan Keberatan diajukan dalam jangka waktu paling lama 1 (satu) bulan sejak tanggal SKRD diterbitkan, kecuali jika Wajib Retribusi dapat menunjukkan bukti keadaan di luar kekuasaannya. Apabila menurut pertimbangan Kepala Dinas, usulan wajib retribusi layak dipertimbangkan, maka Kepala Dinas mengusulkan kepada Walikota guna mendapatkan persetujuan Penetapan.Kepala bidang pengelolaan persampahan wajib memberikan laporan tentang pelaksanaan tugasnya secara berkala serta tepat waktu kepada Kepala Dinas Lingkungan Hidup Kota Bandar Lampung. Setiap satuan Unit dilingkungan bidang pengelolaan persampahan, wajib mengikuti dan mematuhi petunjuk dan bertanggung jawab kepada Kepala bidang pengelolaan persampahan serta emmberikan laporan secara berkala. Setiap laporan yang diterima oleh Kepala bidang pengelolaan persampahan dari setiap satuan Unit, baik Unit Pengembangan dan Pembinaan Pemungutan retribusi pelayanan persampahan/ kebersihan 
ataupun Unit Pengelolaan Retribusi pelayanan persampahan/ kebersihan wajib diolah dan dipergunakan sebagai bahan pertimbangan lebih lanjut serta untuk memberi petunjuk kepada setiap satuan Unit.

Pasal 13 Peraturan Wali Kota Bandar Lampung Nomor 8 Tahun 2019 menjelaskan bahwa Walikota menugaskan Kepala Dinas untuk melakukan pemeriksaan retribusi dalam rangka menguji kepatuhan wajib retribusi. Kepala Dinas Membentuk Tim Pemeriksa Retribusi terdiri dari unsur Dinas /Instansi terkait. Bentuk Pemeriksaan diatur dalam Pasal 14 Peraturan Wali Kota Bandar Lampung Nomor 8 Tahun 2019 sebagai berikut:

(1) Bentuk Pemeriksaan yang terdiri dari:

a. Pemeriksaan Lengkap adalah Pemeriksaan dilakukan di kantor dan di tempat Wajib Retribusi meliputi seluruh jenis Retribusi untuk tahun berjalan dan/atau tahun sebelumnya yang dilakukan dengan menerapkan teknik- teknik pemeriksaan yang lazim digunakan dalam pemeriksaan umum;

b. Pemeriksaan Sederhana adalah Pemeriksaan yang dilakukan ditempat Wajib Retribusi, meliputi jenis retribusi untuk tahun berjalan.

(2) Pemeriksaan sebagaimana dimaksud ayat (1) dapat dilakukan dalam hal:

a. Pemberian dan/atau Pencabutan NPWRD;

b. Pemberian dan/atau Pencabutan NPPKRD;

c. Menentukan besarnya jumlah anggsuran Retribusi dalam suatu masa retribusi bagi Wajib Retribusi;

d. Wajib Retibusi mengajukan keberatan;

e. Pencocokan dan/atau mencari alat keterangan lain.

Pemeriksaan retribusi merupakan perwujudan dari pengawasan, sebagai proses dalam mengukur kinerja dan pengambilan tindakan yang dapat mendukung pencapaian hasil yang diharapkan sesuai dengan tujuan yang telah ditetapkan sebelumnya. Demikian pula dengan kebijakan yang tidak terlepas dari pengawasan kebijakan itu sendiri, karena setiap kebijakan yang telah dibuat tidak dapat dibiarkan begitu saja tetapi harus selalu ada fungsi pengawasan dari pihak yang berwenang untuk mengukur sejauh mana kebijakan tersebut dapat menyelesaikan masalah dan mencapai tujuan yang diharapkan. Dalam hal ini pengawasan pelaksanaan kebijakan merupakan salah satu unsur penting. Sehingga pelaku pengawasan kebijakan pun harus memiliki kemapuan dan keahlian di bidangnya agar dapat emncapai hasil yang diharapkan. Pengawasan kebijakan dapat berasal dari internet dan eksternal pembuat kebijakan sehingga ada keseimbangan dan check and balances dalam implementasi kebijakan tersebut. Lahirnya Undang-Undang 
Nomor 28 Tahun 2009 tentang Pajak dan Retribusi daerah menegaskan keberadaan retribusi daerah sebagai salah satu sumber pendapatan daerah. Didalamnya ditentukan bahwa retribusi adalah pungutan daerah sebagai pembayaran atas jasa atau pemberian izin tertentu yang khusus disediakan dan/atau diberikan oleh Pemerintah Daerah untuk kepentingan orang pribadi atau Badan.

Landasan hukum yang cukup akan menjamin keabsahan kewenangan pemerintah daerah dalam menyusun sebuah kebijakan dalam bentuk peraturan daerah. Selain itu pemetaan kewenangan juga dibutuhkan agar peraturan daerah yang akan disusun tidak bertentangan dengan peraturan yang lebih tinggi dan kepentingan umum. Sehubungan dengan hal tersebut akan dipetakan substansi peraturan perundang-undangan yang mengatur tentang kewenangan pemerintah daerah dalam penyelenggaraan dan retribusi pelayanan persampahan/kebersihan. Pemeriksaan dilakukan dengan berpedoman pada norma pemeriksaan yang berkaitan pada ruang lingkup pemeriksaan retribusi dan Wajib Retribusi.

Pasal 16 Peraturan Wali Kota Bandar Lampung Nomor 8 Tahun 2019 menjelaskan sebagai berikut:

(1) Dalam hal Wajib Retribusi tertentu tidak membayar tepat pada waktunya atau kurang membayar, dikenakan sanksi administratif berupa bunga sebesar 2\% (dua persen) setiap bulan dari Retribusi yang terutang yang tidak atau kurang dibayar dan ditagih dengan menggunakan STRD.

(2) Penagihan Retribusi terutang sebagimana dimaksud pada ayat (1) didahului dengan Surat Teguran.

(3) Pelanggaran terhadap ketentuan-ketentuan yang diatur dalam Peraturan Walikota ini akan dikenakan sanksi administrasi berupa:

a. Peringatan tertulis;

b. Penghentian sementara pelayanan umum bagi pelanggar;

Uraian mengenai kebijakan pemungutan retribusi pelayanan persampahan kebersihan dalam rangka peningkatan Pendapatan Asli daerah di Kota Bandar Lampung sesuai dengan teori sistem hukum Lawrence Friedman bahwa hukum terdiri dari struktur hukum (legal structure), substansi hukum (legal substance) dan budaya hukum (legal culture). Adapun uraiannya adalah sebagai berikut:

1. Struktur hukum (legal structure)

Struktur hukum dalam hal ini adalah Dinas Lingkungan Hidup Kota Bandar Lampung, khususnya Bidang Pengelolaan Sampah yang mempunyai tugas pokok merumuskan dan melaksanakan kebijakan serta kewenangan dibidang pengelolaan sampah. Bidang Pengelolaan Sampah dipimpin oleh 
seorang kepala bidang yang dalam melaksanakan tugasnya bertanggung jawab kepada kepala dinas. Dinas Lingkungan Hidup Kota Bandar Lampung melaksanakan kewenangan dalam pengelolaan sampah sesuai dengan tugas pokok dan fungsinya. Adanya dasar hukum menjadikan Dinas Lingkungan Hidup memiliki acuan dalam melaksanakan berbagai peranan di bidang pengelolaan sampah, artinya berbagai langkah yang ditempuh dalam melaksanakan peranan tersebut disesuaikan dengan kebijakan atau peraturan yang ada.

2. Substansi hukum (legal substance)

Substansi hukum dalam hal ini adalah Perda Nomor 5 Tahun 2011 tentang Retribusi Jasa Umum Pelayanan Persampahan oleh Dinas Lingkungan Hidup Kota Bandar Lampung. Perda ini menjadi dasar hukum pemungutan retribusi pelayanan persampahan kebersihan dalam rangka peningkatan Pendapatan Asli Daerah. Selain itu pemberlakuan Peraturan Wali Kota Bandar Lampung Nomor 8 Tahun 2019 tentang Tata Cara Pelaksanaan Pemungutan Retribusi Pelayanan Persampahan/Kebersihan pada Dinas Lingkungan Hidup menunjukkan adanya penerapan aturan hukum dan perundang-undangan yang berkeadilan serta harus ditegakkan dan dipatuhi secara utuh dalam penyusunan anggaran. Penyelenggaraan pemerintahan yang baik harus didasarkan pada pengaturan hukum yang baik pula.

3. Budaya hukum (legal culture)

Budaya hukum (legal culture) yang dimaksud adalah adanya sistem kerja sumber daya manusia sebagai pelaksanaan kewenangan Dinas Lingkungan Hidup Kota Bandar Lampung dalam pengelolaan sampah yang menggerakan seluruh aktivitas atau kegiatan yang telah ditetapkan oleh organisasi. Keberhasilan suatu organisasi sangat ditentukan oleh dukungan dan kemampuan sumber daya manusianya. Apabila sumber daya manusianya baik dan berkualitas maka tujuan organisasi akan dapat dicapai secara optimal. Hal lain yang mendukung adalah tersedianya sarana dan prasarana dalam pengelolaan sampah. Arti penting pengelolaan sampah bagi Pemerintah Daerah adalah adanya tuntutan pada era otonomi daerah untuk dapat melaksanakan pelayanan kepada masyarakat, termasuk di dalamnya pelayanan persampahan secara baik dalam rangka mewujudkan kelestarian lingkungan hidup. Pada pada sisi lain masyarakat yang menerima layanan dikenakan kewajiban membayar retribusi atas pelayanan persampahan yang diberikan. 


\section{B. Faktor-Faktor Penghambat Kebijakan Pemungutan Retribusi Pelayanan Persampahan Kebersihan Dalam Rangka Peningkatan Pendapatan Asli daerah di Kota Bandar Lampung}

\section{Masih Rendahnya Pemahaman Subjek Retribusi terhadap Produk Hukum Daerah}

Sahriwansah menjelaskan bahwa pemahaman yang dimaksud adalah pemahaman Subjek Retribusi terhadap produk hukum daerah tentang Retribusi Pelayanan persampahan/kebersihan yaitu Peraturan Wali Kota Bandar Lampung Nomor 8 Tahun 2019 tentang Tata Cara Pelaksanaan Pemungutan Retribusi Pelayanan Persampahan/Kebersihan pada Dinas Lingkungan Hidup. Adapun subjek retribusi pelayanan persampahan/kebersihan sebagaimana dimaksud Pasal 11 Peraturan Daerah Kota Bandar Lampung Nomor 5 Tahun 2011 adalah orang pribadi atau badan yang menggunakan atau menikmati pelayanan persampahan/kebersihan yang diselenggarakan oleh pemerintah daerah.

Kepala Dinas Lingkungan Hidup Kota Bandar Lampung, diketahui bahwa pada umumnya Subjek Retribusi memiliki pemahaman yang terbatas bahwa Retribusi Pelayanan persampahan/kebersihan adalah wujud dukungan kepada Pemerintah Daerah dalam penyelenggaraan pembangunan dan kesejahteraan rakyat. Pembayaran Retribusi Pelayanan persampahan/kebersihan merupakan kontribusi kongkrit perusahaan dalam pembangunan di Kota Bandar Lampung. Hal ini menunjukkan Subjek Retribusi kurang memahami hakikat Retribusi Pelayanan persampahan/kebersihan.. Kendala ini memerlukan solusi yaitu perlu ditingkatkan sosialisasi Peraturan Wali Kota Bandar Lampung Nomor 8 Tahun 2019 tentang Tata Cara Pelaksanaan Pemungutan Retribusi Pelayanan Persampahan/Kebersihan pada Dinas Lingkungan Hidup untuk meningkatkan pemahaman terhadap Retribusi Pelayanan persampahan/kebersihan.

\section{Masih Rendahnya Kesadaran Subjek Retribusi Terhadap Pembayaran Retribusi}

Sahriwansah menjelaskan bahwa faktor kesadaran Subjek Retribusi merupakan faktor yang menentukan realisasi retribusi pelayanan persampahan/kebersihan Kepada Kota Bandar Lampung. Pada kenyataannya banyak Subjek Retribusi yang mengganggap bahwa Retribusi Pelayanan persampahan/kebersihan terasa memberatkan perusahaan karena perusahaan telah dibebani kewajiban membayar pajak kepada Pemerintah Kota Bandar Lampung. kesadaran perusahaan bahwa pemberian Retribusi Pelayanan persampahan/kebersihan tidak mengurangi kewajiban yang 
bersangkutan Pemerintah seperti pembayaran pajak sesuai dengan peraturan perundang-undangan yang berlaku.

Peraturan Wali Kota Bandar Lampung Nomor 8 Tahun 2019 tentang

Tata Cara Pelaksanaan Pemungutan Retribusi Pelayanan Persampahan/Kebersihan pada Dinas Lingkungan Hidup merupakan salah satu jenis Peraturan Perundang-undangan dan merupakan bagian dari sistem hukum nasional yang berdasarkan Pancasila. Saat ini di era otonomi daerah Peraturan Daerah memiliki peranan yang sangat strategis karena memiliki landasan konstitusional yang jelas sebagaimana diatur dalam Pasal 18 ayat (6) Undang-Undang Dasar 1945.

\section{PENUTUP}

\section{A. Kesimpulan}

Kebijakan pemungutan retribusi pelayanan persampahan kebersihan dalam rangka peningkatan Pendapatan Asli daerah di Kota Bandar Lampung sudah dilaksanakan tetapi belum maksimal. Pelaksanaan tersebut dilakukan dengan penyusunan perencanaan untuk merancang strategi pemungutan retribusi pelayanan persampahan/kebersihan yang dapat meningkatkan PAD, menerapkan sarana atau perangkat pekerjaan yang mempermudah pelaksanaan pemungutan retribusi pelayanan persampahan/ kebersihan secara efektif dan efesien dan melaksanakan mekanisme pemungutan retribusi pelayanan persampahan/ kebersihan secara jelas dan menerapkan sistem evaluasi dalam bentuk pemeriksaan dalam rangka mengontrol atau memastikan bahwa pemungutan retribusi pelayanan persampahan/kebersihan sesuai dengan perencanaan yang telah ditetapkan sebelumnya.

Faktor-faktor penghambat pelaksanaan pemungutan retribusi pelayanan persampahan/kebersihan berdasarkan Peraturan Wali Kota Bandar Lampung Nomor 8 Tahun 2019 tentang Tata Cara Pelaksanaan Pemungutan Retribusi Pelayanan Persampahan/Kebersihan pada Dinas Lingkungan Hidup adalah masih rendahnya pemahaman Subjek Retribusi terhadap produk hukum daerah tentang Retribusi Pelayanan persampahan/kebersihan dan masih rendahnya kesadaran Subjek Retribusi terhadap retribusi yang dianggap memberatkan karena telah dibebani kewajiban membayar pajak kepada Pemerintah Kota Bandar Lampung. 


\section{B. Saran}

1) Kepala Dinas Lingkungan Hidup Kota Bandar Lampung disarankan untuk mensosialisasikan Peraturan Wali Kota Bandar Lampung Nomor 8 Tahun 2019 tentang Tata Cara Pelaksanaan Pemungutan Retribusi Pelayanan Persampahan/Kebersihan pada Dinas Lingkungan Hidup secara lebih intenstif kepada subjek retribusi agar tidak terjadi kurangnya pemahaman tentang retribusi pelayanan persampahan/kebersihan

2) Kepala Dinas Lingkungan Hidup Kota Bandar Lampung disarankan untuk meningkatkan pengawasan terhadap pelaksanaan pemungutan retribusi yang dilakukan oleh petugsas di lapangan, sehingga tidak terjadi ketidak akuratan antara data yang ada dengan fakta yang ada di lapangan serta mengantisipasi keterlambatan atau penyimpangan dalam hal pembayaran retribusi.

3) Kepala Dinas Lingkungan Hidup Kota Bandar Lampung disarankan untuk menerapkan sanksi atau hukuman yang sesuai kepada oknum pegawai yang terbukti melakukan pungutan liar dalam penarikan retribusi persampahan, mengingat perbuatan yang dilakukan tersebut merugian keuangan daerah, khususnya Pendapatan Asli Daerah yang bersumber dari retribusi pelayanan persampahan/kebersihan. 


\section{DAFTAR PUSTAKA}

Ahmad Slamet. 2014. Teknik Mengelola Sampah Ramah Lingkungan. Bina Cipta, Bandung

Arifin Hussein. 2012. Manajemen Pengelolaan Sampah Modern. Penerbit Andi, Yogyakarta

Bagir Manan. 2012. Menyongsong Fajar Otonomi Daerah. Pusat Studi Hukum, UII, Yogyakarta.

Ryaas Rasyid. 2011. Desentralisasi dalam Rangka Menunjang Pembangunan Daerah. LP3ES, Jakarta

Dimas Harjoko. 2012. Sampah dalam Kebijakan Pemerintah, UNS, Semarang

Jefferson Rumajar. 2013. Otonomi Daerah: Sketsa. Gagasan dan Pengalaman. Media Pustaka, Manado

Lintje Anna Marpaung, 2016, Revitalisasi Hukum Otonomi Daerah dan Prospektif Kepentingan Daerah, Aura Publishing, Bandar Lampung

Mahfud MD. 2011. Pergulatan Politik dan Hukum di Indonesia. Yogyakarta, Gema Media

Malayu S.P. Hasibuan. 2014. Organisasi dan Manajemen. Rajawali Press. Jakarta

Mardjono Reksodiputro, 2012, Sistem Peradilan Pidana Indonesia (Melihat Kejahatan dan Penegakan Hukum dalam Batas-Batas Toleransi), Pusat Keadilan dan Pengabdian Hukum, Jakarta

R Baswir. 2012. Paradigma Baru Pengelolaan Keuangan Daerah dalam Pelaksanaan Otonomi Daerah.MEP-UGM, Yogyakarta

Soerjono Soekanto dan Sri Mamudji. 2014. Penelitian Hukum Normatif, Rineka Cipta, Jakarta,

Undang-Undang Dasar Negara Republik Indonesia Tahun 1945 Hasil Amandemen Keempat

Undang-Undang Nomor 32 Tahun 2009 tentang Pengelolaan Lingkungan Hidup 
Undang-Undang Nomor 18 Tahun 2008 tentang Pengelolaan Sampah

Undang-Undang Nomor 28 Tahun 2009 tentang Pajak Daerah dan Retribusi Daerah

Undang-Undang Nomor 12 Tahun 2011 tentang Pembentukan Peraturan Perundang- Undangan

Undang-Undang Nomor 23 Tahun 2014 Jo. Undang-Undang Nomor 9 Tahun 2015 tentang Pemerintahan Daerah

Peraturan Pemerintah Nomor 38 Tahun 2007 tentang Pembagian Urusan Pemerintahan Antara Pemerintah, Pemerintahan Daerah Provinsi dan Pemerintahan Daerah Kabupaten/Kota

Peraturan Daerah Kota Bandar Lampung Nomor 5 Tahun 2011 tentang Retribusi Jasa Umum Pelayanan Persampahan.

Peraturan Daerah Kota Bandar Lampung Nomor 7 Tahun 2016 tentang Pembentukan dan Susunan Perangkat Daerah Kota Bandar Lampung. Dasar hukum lainnya

Peraturan Walikota Bandar Lampung Nomor 47 Tahun 2016 tentang Tugas, Fungsi dan Tata Kerja Dinas Lingkungan Hidup Kota Bandar Lampung

Peraturan Walikota Bandar Lampung Nomor 8 Tahun 2019 tentang Tata Cara Pelaksanaan Pemungutan Retribusi Pelayanan Persampahan pada Dinas Lingkungan Hidup Kota Bandar Lampung 


\section{PEDOMAN PENULISAN \\ JURNAL PRANATA HUKUM}

1. Naskah bersifat orisinil, baik berupa hasil riset atau tinjauan atas suatu permasalahan hukum yang berkembang di masyarakat (artikel lepas), dimungkinkan juga tulisan lain yang dipandang memberikan kontribusi bagi pengembangan ilmu hukum.

2. Penulisan terdiri atas beberapa bab penulisan hasil penelitian terdiri dari $3 \mathrm{BAB}$, yaitu ;

BAB I. PENDAHULUAN (Latar Belakang dan Rumusan Masalah) BAB II. PEMBAHASAN (Kerangka Teori dan Analisis), dan BAB III. PENUTUP (Kesimpulan dan Saran).

3. Tulisan menggunakan bahasa indonesia maupun bahasa inggris yang memenuhi kaidah bahasa yang baik dan benar,tulisan menggunakan bahasa indonesia disertai abstrak dalam bahasa inggris (200 kata) dan Kata kunci, ketentuan ini berlaku sebaliknya.

4. Setiap kutipan harus menyebutkan sumbernya dengan format footnote. Sumber kutipan harus memuat nama pengarang, tahun penerbitan, judul buku, nama penerbit, kota penerbit, dan halaman. Contoh : Bagir Manan. 1994. Hubungan Antara Pemerintah Pusat dan Daerah Menurut UUD 1945. Pustaka Sinar Harapan. Jakarta. 1994, hlm. 19. Untuk artikel dari internet dengan susunan: nama penulis, judul tulisan digaris bawah, alamat website, waktu download/unduh.

5. Naskah harus disertai dengan daftar pustaka atau referensi ,terutama yang digunakan sebagai bahan acuan langsung. Daftar pustaka dan referensi bersifat alfabetis dengan format; nama pengarang, judul buku, nama penerbit, kota terbit, dan tahun penerbitan. Contoh: Bagir Manan. 1994. Hubungan Antara Pemerintah Pusat dan Daerah Menurut UUD 1945. Pustaka Sinar Harapan. Jakarta.

6. Panjang tulisan antara 15-25 halaman, font cambria dengan 1,15 spasi. Dalam hal hal tertentu berlaku pengecualian panjang tulisan.

7. Naskah disertai nama lengkap penulis, alamat e-mail dan lembaga tempat berafiliasi saat ini, dan hal lain yang dianggap penting. 
Jurnal PRANATA HUKUM dimaksudkan sebagai media komunikasi, edukasi, dan informasi ilmiah bidang ilmu hukum khususnya, dan ilmu sosial pada umumnya. Sajian dan kemasan diupayakan komunikatif melalui bahasa ilmiah.

Redaksi mengundang semua elemen masyarakat baik civitas akademika, praktisi, lembaga masyarakat, maupun perorangan yang berminat terhadap bidang hukum untuk berpartisipasi mengembangkan gagasan, wawasan, dan pengetahuan melalui tulisan untuk dimuat dalam jurnal ini.

Melalui PRANATA HUKUM diharapkan terjadi proses pembangunan dan pengembangan bidang hukum sebagai bagian penting dari rangkaian panjang proses memajukan masyarakat bangsa.
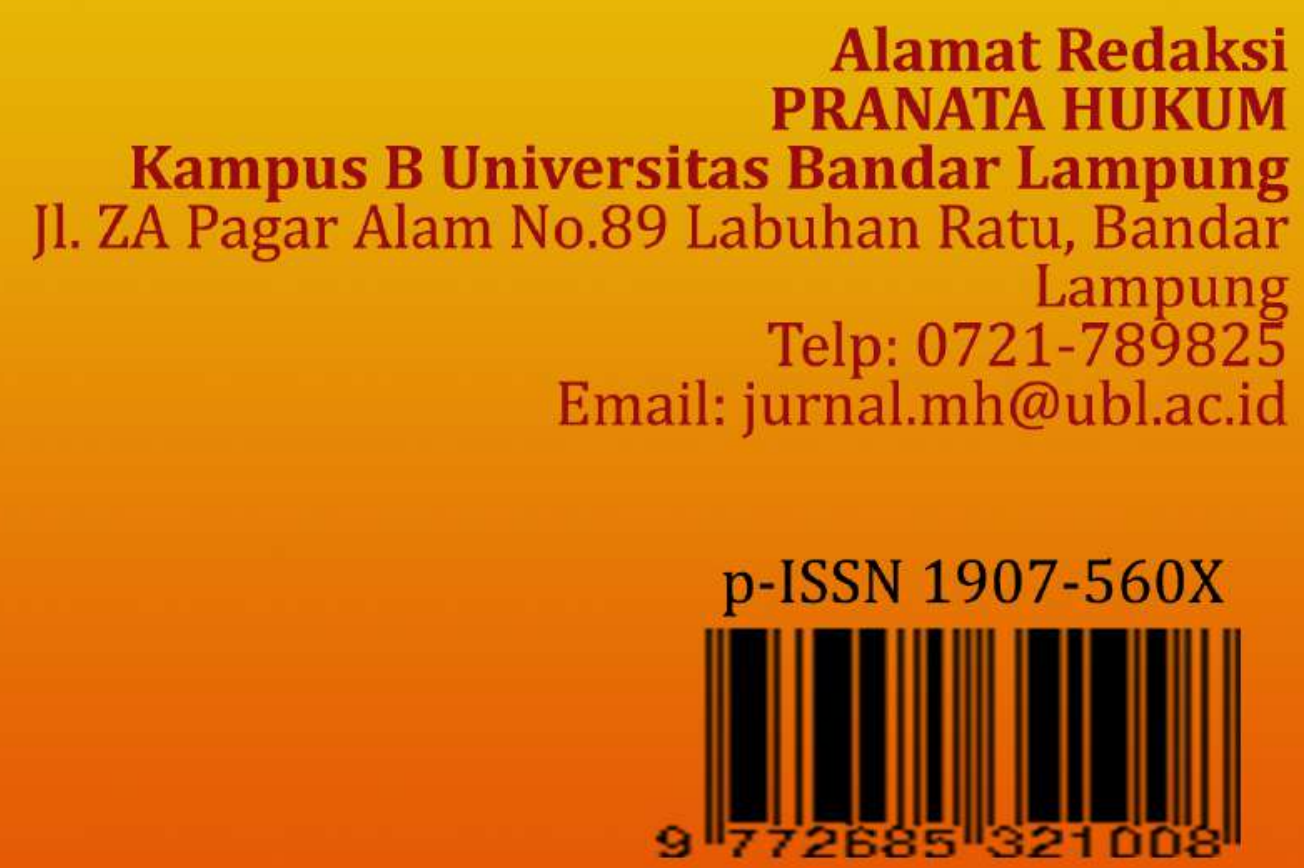